\title{
Universiteit
}

Leiden

The Netherlands

\section{Regionalism in history, 1890-1945: The cultural approach}

Storm, H.J.

\section{Citation}

Storm, H. J. (2003). Regionalism in history, 1890-1945: The cultural approach. European History Quarterly, 251-266. Retrieved from https://hdl.handle.net/1887/14077

Version: $\quad$ Not Applicable (or Unknown)

License: $\quad$ Leiden University Non-exclusive license

Downloaded from: https://hdl.handle.net/1887/14077

Note: To cite this publication please use the final published version (if applicable). 


\title{
Regionalism in History, 1890-1945: \\ The Cultural Approach
}

\author{
Eric Storm
}

Post-print

Original in:

European History Quarterly

Volume 33 Number 2 April 2003

p. 251-267

copyright Sage publishers 


\section{Regionalism in History, 1890-1945: \\ The Cultural Approach}

In the last few decades, there has been renewed interest in the region all over Europe: Regional differences and traditions are cherished, the issue of regional identity is widely debated, regional movements are in the limelight, and historians have started to reconsider the role of the region. In response to this, in October 1999 the American Historical Review published a forum entitled 'Bringing Regionalism Back to History.'

In the first historiographic article, Celia Applegate shows that after 1945 the region was almost completely ignored as an object of historical analysis. The dominant modernization theory assumed that the separate regional economies, politics, and cultures were doomed to be swallowed up by the nation. It was only after historical sociologists, like Immanuel Wallerstein and Stein Rokkan, came up with the center-periphery model in the 1970s that the region received new attention. Research focused on local and regional economic differences and on the political

modernization of peripheral regions. ${ }^{1}$ A good example of this approach is offered by the 1994 special issue of Geschichte und Gesellschaft, which was dedicated to 'Nationalism and Regionalism in Western Europe.' The articles in it deal with Northern Ireland, Catalonia, the Basque Country, and various 'underprivileged' regions within France. ${ }^{2}$

According to Applegate, historical geographers in the last few decades also did a lot of scholarly research on the region. However, a third approach seems to be the most promising. Inspired by anthropological and sociological studies on the 'ontology of groupness,' historians have begun to focus on nationalism and national identity, and lately also on local and regional identity. Of interest in this cultural approach are all regions, rather than only the 'unhappy regions' in which the national identity was contested. ${ }^{3}$ Moreover, in recent debates on nationalism it is recognized that 
a human being can have multiple identities. Territorial identities - local, regional, national, and supranational - do not have to be conflicting; on the contrary, people have different layers of identity that supplement each other. ${ }^{4}$

This new cultural approach to regionalism has already produced some remarkable results. After discussing some recent studies on regionalism in the period 1890-1945 - with the focus on

Germany, France, and Spain - I will argue that the importance of the process of regional identity construction during this period has not been fully recognized. This process not only caused a growing interest in the regional cultural and natural heritage, but also affected almost all areas of European high culture during the first half of the twentieth century. Only a comparative perspective - in which different regions and nations are compared, and the influence of regionalism on all kinds of cultural practices is taken into account - can do justice to this complex historical phenomenon. Such will show that regionalism in the decades before 1945 was the guise in which the widely accepted Volksgeist discourse was dressed, and that it is almost impossible to understand the cultural developments of this period without taking into consideration its profound and omnipresent influence.

\section{The First Heydays of Regionalism}

Recent research on regionalism has made it clear that in most cases, regional identities supplied the corresponding national identity with local roots. It has also been shown that such regional identities as nations are mainly modern creations, or even outright inventions. The division of France into departments, for example, dates from the French Revolution, whereas many German regions were created during the Napoleonic period. Therefore, the corresponding regional identity is, just like that of nations, essentially a modern creation; this even applies to older regions like Catalonia, Britanny, and Saxony. ${ }^{5}$ This does not mean, however, that all regional identities were equally strong 
and widely diffused, or that all regional movements had similar goals, as only some of them especially after 1900 - started to strive for cultural and political autonomy.

Further, it has become clear that regions were not passive entities that underwent an imposed process of nation-building without having any influence upon it. The view, as defended by Eugen Weber and others, ${ }^{6}$ that a national élite imposed - by means of education, military service, improved communications, and political propaganda - a process of nationalization upon the periphery, has been contested. Authors like Sahlins, Applegate, Tacke, and Baycroft have shown that local and national identities were not necessarily conflicting and that provincial élites played an active role in the nation-building process. Peripheral communities often urged the state to play a more active role in their region by invoking their national identity. ${ }^{7}$

The character of regionalism - the movement that promoted the study and reinforcement of regional identity - changed profoundly around 1890 . During most of the nineteenth century, the study of the own region was almost exclusively the work of members of learned societies or associations. The major themes of research and debate were the historical, archaeological, and geographical background of the region, and its significance within the national context. Although these societies generally professed a pedagogical vocation, the writings they produced and the lectures they organized were mainly intended for their members, who were recruited from a small élite of local notables. In fact, one can even doubt whether regionalism was the focus of these associations, as the region was considered from a national perspective. In general, it was the historical contribution of the own region to the greatness of the fatherland that mattered, not the idiosyncratic identity that distinguished the region from the whole.

This changed only at the end of the nineteenth century, when a group of young, welleducated members of the provincial élite wanted to reach a broader public. This required other forms of expression and sociability. Instead of promoting scholarly studies, the new associations 
tried to mobilize the middle and popular classes. These were encouraged to participate in essentially recreational activities - by organizing excursions and festivals, and establishing local museums and to celebrate a shared identity which was not constituted by a mythic past, but mainly by contemporary popular culture like folklore, handicrafts, and vernacular architecture. This réveil des provinces occurred at about the same time all over Europe, converting regionalism into a mass movement. ${ }^{8}$ Tourism and the widespread reproduction of images of places of interest in picture books, travel guides, and illustrated magazines, and on picture postcards, also contributed to a growing awareness of the existence of specific regional identities, each with its typical products, architecture, cuisine, dress, and landscape. However, a distinction should be made between regional self-awareness and the external tourist image that did not necessarily coincide with it. ${ }^{9}$

Karl Ditt, a specialist on the German Heimat movement, calls this regionalist Heimat- and Volkstumskultur one of the five important cultural forms of the period between the end of the nineteenth and the middle of the twentieth century. He also mentions high culture, avant-garde culture, working-class culture, and mass culture. According to him, the last two forms created their own separate sphere, whereas the Heimatkultur and the avant-garde started to compete with the existing high culture. The avant-garde attacked the outdated esthetical norms that hampered artistic freedom and creativity. The Heimatbewegung, in turn, criticized the élitist and cosmopolitan character of high culture. Instead of an international genius-driven cultural progress, its representatives tried to stimulate the organic growth of a popular culture that had its roots in the Volksgeist. The individual was not free, but bound by nature, the past, and tradition. All cultural expressions had to be oriented on this common background. If they were not, the result would be collective degeneration. $^{10}$

The guiding principle behind this mode of thinking was the idea that each people had its own 'spirit', 'soul', or 'nature', which could be distilled from its cultural expressions. This idea which was mostly labeled Volksgeist - became widely accepted during the Romantic era. It lay at 
the foundation of the historicism that dominated many parts of nineteenth-century high culture, and was extensively used in the early phases of national identity construction. ${ }^{11}$ During the second half of the nineteenth century, however, this idea was eclipsed by the growing success of the natural sciences. Nevertheless, somewhat transformed by organic and biological ideas (which had become popular thanks to Darwin), the Volksgeist discourse made a strong comeback at the end of the nineteenth century. Many thinkers now compared the nation with an organism whose health was determined by the wellbeing of its constituent parts. But whereas at the start of the century the emphasis had been on the whole, thus legitimizing the nation vis-à-vis the forces of the ancien régime, now the stress was put on the region in order to underline the intimate bond between everyone's own community and the nation. Every region had its own identity shaped by the agelong interaction between the local population and its natural environment. Only by being faithful to its own character could the region contribute to the welfare of the whole.

Although regionalism has often been interpreted as a reactionary movement, this was not the case to begin with. Like other reform movements at the end of the nineteenth century, regionalists criticized classical laissez-faire liberalism for ignoring local differences and declining any state intervention. Furthermore, the regional movement with its stress on participation and its anti-élitism also had a democratic component, and its participants were drawn essentially from the modern, urban middle classes.

The Volksgeist discourse should not be confounded with racial thought. Often racial arguments were mixed up with more cultural explanations, and many adherents of the regional movement made anti-Semitic or racist statements. Nevertheless, racial doctrines were fundamentally based on a biological determinism, whereas the Volksgeist theory presupposed that people interact with their environment. Whereas the physical milieu and historical traditions determine the character of a people, they are to a certain extent shaped and transformed by the people. Racial factors could play a role, but were never predominant. Jews could therefore become 
members of most regional movements and Jewish artifacts were shown at several regional museums. $^{12}$

Around 1900, regionalism became a mainstream movement. Every region had its own 'soul', and as an organic part of the nation its particular character should be studied and reinforced. Particularly the interwar period became the golden age of regionalist popular culture. Heimatmuseums, regional periodicals, folkloric festivals, plays in dialect, regional literature, and handicrafts flowered as never before. Preservation of typical natural scenery, regional architecture, and popular arts as parts of the regional heritage was seen as a vital necessity.

The ascendancy of the various European Fascist parties constituted an important turning point in the history of regionalism. Many of its activists accepted or even supported the new Fascist regimes, as they hoped to realize their ideal of a harmonious society in line with national and regional traditions within the new state. In general, the Fascist parties agreed with part of the regionalist program, like the idyllic notion of an untouched countryside as the heartland of the nation. They also recognized the importance of local traditions and popular culture. Nevertheless, other aspects of their ideology were openly opposed to regionalist thought and practice. The strong centralism of the new regimes, their populism, cult of violence, modernism, totalitarian character, and (in the German case) racism were incompatible with the mostly very multiform regionalist movements. This was also visible because Fascist dictators generally preferred huge constructions in a monumental, neo-classical style rather than small-scale buildings that respected local construction traditions. Contrary to the expectations of many regionalists, regionalism did not really prosper in the new states. Some of its projects were realized, but in general the regional movement was purged of undesirable elements, had to follow the instructions of the new leaders, and finally was openly deployed to realize the goals of the Fascist regimes. ${ }^{13}$

The collaborative attitude of many regionalists and the appropriation of regionalism by the Fascists determined the historiographic fate of the movement. After 1945 the regional movement 
was generally judged negatively, and as far as it was studied, it was generally seen as an ideological

forerunner of Fascism and a negative, backward-looking force. ${ }^{14}$ As Applegate has argued, it is only recently that regionalism has been studied in its own right. Particularly its most salient aspects receive scholarly attention, like the many regional associations, the rise of historical preservation, excursionism, environmental protection, ethnography, folklore, popular art, and regional literature. ${ }^{15}$ However, not only did the new interest in regional popular culture lead to the creation of a new branch of scientific research - ethnography - but regionalism also heavily influenced high culture and various avant-garde movements. And this has generally been overlooked by most historians.

\section{Regionalism and High Culture}

The Volksgeist discourse and the regional movement that was based on it were omnipresent in debates on politics and culture during the period 1890-1945. Social scientists and representatives of the cultural establishment extensively used its arguments and terminology, while artists, writers, architects, and composers used popular motives in their creations. A brief look at architecture and the visual arts will make it evident that regionalism had a huge impact on the European high culture of this period.

One of the best examples of the regionalist current in the visual arts is the Spanish painter Ignacio Zuloaga (1870-1945). In the early 1890s, Zuloaga studied painting in Paris, where he became acquainted with Degas, Puvis de Chavannes, Signac, Toulouse-Lautrec, Bernard, Gauguin, and many other leading artists. After trying various styles, in 1895 he left bohemian Paris for Seville to live in a traditional corral among ordinary people. There he developed a personal style, painting such archetypal characters as bullfighters and dancers against the background of a typical local landscape. Although he was born in the Basque Country, he preferred to paint southern and 
central Spanish themes. He therefore also stayed for longer periods in Segovia and Pedraza, where he painted life-sized Castilian villagers in their natural environment. Trying to capture the psychology of his models, he also intended to depict the collective 'soul' or 'spirit' of various Spanish regions. His paintings enjoyed enormous success at Parisian salons and at international exhibitions in Europe and the Americas, and were taken serious by leading critics and artists. In 1904, for example, he was honored, together with Menzel and Rodin (who became a good friend of his), by being given a whole room at a major international art exhibition in Düsseldorf. ${ }^{16}$

Joaquín Sorolla (1863-1923), another highly successful Spanish painter, also became involved with regionalism. In 1911 he was asked by the Hispanic Society of America to paint a series of huge canvasses for its library, representing Spain. He chose to paint cheerful folkloric scenes in bright colors, depicting the mostly female figures against a typical natural background. In this way, he gave a different interpretation of the character - or 'soul' - of the various Spanish regions. Other Spanish painters also tried to capture the collective spirit of certain regions or areas. Most of them preferred to paint their own region: Thus Romero Torres depicted Andalusia; Valentín de Zubiaurre, the Basque Country; Santa María, Castile; and Álvarez de Sotomayor, Galicia. $^{17}$

However, this genre was not exclusively Spanish, nor had it originated there. From about 1890, painters all over Europe started to substitute anonymous, poorly dressed farmers doing hard work in their representations of the countryside, for characteristic types in traditional dress against a typical local background. In France, Lucien Simon and Charles Cottet painted typical Breton scenes, whereas Charles Milcendeau specialized in images of rural life in the Vendée. In Germany, Heimatkunst became fashionable as well. Hans Thoma, Albin Egger-Lienz, and some of the Worpsweder painters were its best-known representatives. ${ }^{18}$

Art criticism, too, was pervaded by the Volksgeist discourse. Critics like Bernard, Montesquiou, and Denis in France, and Thode, Vinnen, and Moeller van den Bruck in Germany 
argued that real art had to orient itself on the Volksgeist. An earth-bound art that respected national and regional cultural and pictorial traditions was morally superior to other kinds of art. They especially attacked the internationalist, 'soulless' and 'uprooted' art that had started to dominate the international art world. This mode of thinking was not a minority affair, but was highly influential and even affected some avant-garde movements. For example, the Fauves came up with a new interpretation of French identity, propagating the Mediterranean coast as a typically national landscape, and the German expressionist movement Der blaue Reiter defined its art as transcendental, inspired by gothic spirituality and therefore typically Nordic or German. ${ }^{19}$

Regionalism also became conspicuous in town planning, a sphere in which the ideas of the Viennese theorist Camillo Sitte were highly influential. In Der Städtebau (1893), Sitte stressed the importance of esthetic principles and encouraged the building of unified, organic ensembles that would stimulate people's sense of belonging. Also the garden city movement - which started in England around the turn of the twentieth century, and almost immediately spread to the Continent was influenced by the Volksgeist discourse. However, regionalism was translated in a more direct way in architecture. From about 1900, many architects and critics began to argue that local materials, building traditions, and styles should be respected. Buildings should be in harmony with both their physical environment and the regional architectural traditions. After the First World War, this kind of regionalist architecture became really fashionable. Everywhere houses, villas, and even monumental buildings were constructed in a vernacular style. Prominent propagators of this movement were Marcel Poète, Gaston Bardet, and Alfred Agache in France, Paul SchultzeNaumburg, Robert Mielke, and Theodor Fischer in Germany, and Leopoldo Torres Balbás, Leonardo Rucabado, and Aníbal González Álvarez in Spain. During the first decades of the twentieth century, even emblematic avant-garde architects like Mies van der Rohe, Bruno Taut, and Hans Poelzig designed buildings in a pronounced Heimatstil. ${ }^{20}$ 
That regionalism was seen as a serious alternative to high culture and the avant-garde became clear in the 1920s and 1930s, when some countries decided to present themselves at international expositions as an ensemble of regions. Elements of regionalist culture had been present at this kind of exposition for a long time: Already at the Paris World's Fair of 1867 the participating nations were encouraged to expose their exhibits in constructions that were considered typical for their country. At the World's Fair in Vienna in 1873, an international village was built and from then on every international exposition had its Rue des nations, an 'old Antwerp, Paris or Vienna,' and a Russian, German, or Swiss village. Although machinery, new inventions, and high art still dominated these expositions, ethnographic and colonial shows became an indispensable part of them and greatly contributed to their commercial success. Nevertheless, after the First World War vernacular architecture, traditional dress, and popular art were not shown anymore as a picturesque complement to cover up modernity, but as the essence of the nation. For example, at the Iberian-American Exposition in Seville in 1929, various regional pavilions represented Spain, and at the 1937 Paris World's Fair, France presented itself exclusively with a Centre régional - France being the sum of its regions. Although the plans for this regional show dated from the early 1930s, they were left unchanged by the new Popular Front government. Thus, even the political left embraced regionalism. The regional center was obviously regarded as a success, because at the World's Fair in New York two years later, France did not radically change the formula. ${ }^{21}$

In a recent monograph on the 1937 World's Fair, the art historian James D. Herbert writes only a few lines on the French pavilion, arguing that no one could possibly mistake the Centre régional for France. ${ }^{22}$ This attitude characterizes the historiographic fate of regionalism, as regionalism is not taken seriously by most scholars, and its representatives in most areas of high culture are excluded from the established canons. In the visual arts, the history of modern art and the avant-garde movements has removed regionalist artists from view, whereas the rise of modernism dominates the history of architecture. Furthermore, the impact of the Volksgeist 
discourse on high culture and the avant-garde is mainly ignored or explained as a superficial side effect of the nationalistic climate of the period. Regionalism and its profound influence on high culture, therefore, have been largely disregarded. Possibly, one could even argue that the emphasis most avant-garde movements put on international modernism, and its subsequent canonization by historians, can be explained as a reaction to the strength of pre-1945 regionalist traditionalism. Thus, the fixation on modernism and the neglect of regionalism has not only distorted the picture of both, but has also led to a very biased image of the cultural development of the whole period. ${ }^{23}$

\section{The Denationalization of the Region}

Another issue that deserves serious attention is the inherent nationalism of most of the existing historical studies. As the process of regional identity construction occurred at about the same time all over Europe, it should be studied in an international comparative perspective. However, most scholars, even in recent years, have focussed on one or several regions within one country only. Consequently, they explain the rise of regionalism in national terms. For example, it is argued that regionalism in Germany was a result of the late national unification, the fast process of urbanization and industrialization, and the unsteady position of the Bildungsbürgertum; that in France, the causes were the lost war of 1870 , the relatively weak economic position of the country, and the strongly centralized state bureaucracy; and that in Spain, the causes were the loss of the main colonies in 1898 , the need to regenerate the country, and a centralized but inefficient state. ${ }^{24}$

Moreover, there is a related problem. Most research on nationalism - to which the study of regional identities is closely related - is still embedded in national historiographic traditions.

Charlotte Tacke has rightfully pointed out that in this way all kind of supposed collective characteristics, as they were put forward by nationalists, still guide historical research. Thus the already widely criticized opposition between political and cultural nationalism (or Staatsnation- 
Kulturnation) is still chosen, more or less unconsciously, as the starting-point of many research projects. For example, most German historians focus on expressions of cultural nationalism, whereas in France the republican political nationalism has been a favorite object of analysis. ${ }^{25}$

Only comparative studies - in which the authors should consciously try to avoid national stereotypes and their continuation in nationally framed historiography - will be able to show the similarities, differences, and constants in regionalism, and explain the rise and flowering of this truly international phenomenon. The significance of regionalism in all kinds of cultural areas also deserves serious attention in order to obtain a less one-sided picture of European culture in the fifty years leading up to World War II. Therefore, the almost omnipresent Volksgeist discourse, which was applied by both nationalists and regionalists, should first be analyzed. What were its basic assumptions and arguments, which variants existed, how was it used by various ideological groups, and what local, regional, and national variants came into existence? How was it applied to regional identity construction, and what strategies were used in this process? Who was receptive to its message, and how did it affect all kinds of cultural domains and even opposed movements like the avant-garde? What differences can be discerned and how can these be explained? In this way, regionalism will be no longer studied as an anomaly - which can be explained by some structural weakness in the corresponding nation-building process - but as an integral part of the cultural developments of this crucial period of European history.

\footnotetext{
${ }^{1}$ Celia Applegate, 'A Europe of Regions: Reflections on the Historiography of Sub-National Places in Modern Times', American Historical Review (Oct. 1999), 1157-1183. Most research is still done on these 'underprivileged regions.'

${ }^{2}$ Geschichte und Gesellschaft, XX, Nationalismen und Regionalismen in Westeuropa (1994). The same approach is used in Wilhelm Ribhegge, Europa-Nation-Region (Darmstadt 1991); and Günter Lottes ed., Region, Nation, Europa (Heidelberg 1992).

${ }^{3}$ Applegate, 'A Europe of Regions', 1174-1182.

${ }^{4}$ See for example Anthony D. Smith, Nationalism and Modernism. A Critical Survey of Recent Theories of Nations and Nationalism (London and New York 1998), 201. However, Smith himself prefers the term 'ethnicity' to 'identity.'

${ }^{5}$ Celia Applegate, A Nation of Provincials. The German Idea of Heimat (Berkeley 1990); Alon Confino, 'The Nation as a Local Metaphor: Heimat, National Memory and the German Empire, 1871-1918' History \& Memory (1993), 42-86; Jean-Clément Martin, 'La construction culturelle d'une région, la Vendée' in Heinz-Gerhard Haupt, Michael Müller and Stuart Woolf eds., Regional and National Identities in Europe in the XIXth and XXth Centuries (The Hague 1998), 437465; Manuel Suárez-Cortina, Casonas, hidalgos y linajes. La invención de la tradición cántabra (Santander 1994); Borja de Riquer i Permanyer, Identitats contemporànies: Catalunya i Espanya (Barcelona, 2000); and Thomas Kühne,
} 
'Die Region als Konstrukt. Regionalgeschichte als Kulturgeschichte' in James Retallack ed., Sachsen in Deutschland. Politik, Kultur und Gesellschaft 1830-1918 (Bielefeld, 2000), 253-264.

The discussion between 'modernists' and 'primordialists' on the origins of nations could be applied to regions as well. However, most participants agree that possible older territorial or ethnic loyalties developed into modern nationalism only after about 1790, and the same applies to regionalism. See: Smith, Nationalism and Modernism, passim, and Ernest Gellner, Nationalism (London 1997), 90-102.

${ }^{6}$ Eugen Weber, Peasants into Frenchmen. The Modernization of Rural France, 1870-1914 (Stanford 1976). Many scholars (e.g., Gellner, Hobsbawm, and Benedict Anderson) share this point of view, and consequently most studies on nation-building deal with the ideas and activities of national élites.

${ }^{7}$ Peter Sahlins, Boundaries. The Making of France and Spain in the Pyrenees (Berkeley 1989); Applegate, A Nation of Provincials; Charlotte Tacke, Denkmal im sozialen Raum. Nationale Symbole in Deutschland und Frankreich im 19. Jahrhundert (Göttingen 1995); and Timothy Baycroft, 'Changing identities in the Franco-Belgian Borderland in the Nineteenth and Twentieth Centuries', French History, Vol. XIII (1999-4), 417-438.

${ }^{8}$ See Applegate, A Nation of Provincials, 20-107; Karl Ditt, 'Die deutsche Heimatbewegung 1871-1945' in Will Cremer and Ansgar Klein eds., Heimat. Analysen, Themen, Perspektiven (Bielefeld 1990), 135-155; Dietmar von Reeken, Heimatbewegung, Kulturpolitik und Nationalsozialismus: Die Geschichte der 'Ostfriesische Landschaft' (Aurich 1995), 25-37; Anne-Marie Thiesse, Écrire la France. Le mouvement littéraire régionaliste de langue française entre la Belle Epoque et la Libération (Paris 1991), 17-85, David Hopkin, 'Identity in a Divided Province: The Folklorists of Lorraine, 1860-1960', French Historical Studies XXIII (2000), 640-682; Joan-Lluís Marfany, La cultura del catalanisme. El nacionalisme català en els seus inicis (Barcelona 1995), 23-89; and Xosé-Manoel Núñez, 'The Region as Essence of the Fatherland: Regionalist Variants of Spanish Nationalism (1840-1936)', European History Quaterly, Vol. XXXI (2001), 483-518. See for the Netherlands Ad de Jong, De dirigenten van de herinnering. Musealisering en nationalisering van de volkscultuur in Nederland, 1815-1940 (Nijmegen 2001).

${ }^{9}$ Rudy Koshar, Germany's Transient Pasts. Preservation and National Memory in the Twentieth Century (Chapel Hill 1998), 17-75; Rudy Koshar, "What Ought to Be Seen." Tourist Guidebooks and National Identities in Modern Germany and Europe', Journal of Contemporary History, Vol. XXXIII (1998), 323-340; and Thiesse, Écrire la France, 205-241.

${ }^{10}$ Karl Ditt, 'Konservative Kulturvorstellungen und Kulturpolitik vom Kaiserreich bis zum Dritten Reich', Neue Politische Literatur XLI (1996-2) 230-260, esp. 230-232.

${ }^{11}$ See for example Anne-Marie Thiesse, La création des identités nationales. Europe XVIIIe-XXe siècle (Paris 1999); Monika Flacke ed., Mythen der Nationen. Ein europäisches Panorama (Berlin 1998); and José Álvarez Junco, Mater Dolorosa. La idea de España en el siglo XIX (Madrid, 2001).

12 Applegate, A Nation of Provincials, pp. 67, 77 and 100. See for more racially inspired movements, Uwe Poschner, Die völkische Bewegung im wilhelminischen Kaiserreich. Sprache, Rasse, Religion (Darmstadt, 2001).

${ }^{13}$ Koshar, Germany's Transient Pasts, 151-199; Karl Ditt, ""Mit Westfalengruß und Heil Hitler". Die Westfälische Heimatbewegung 1918-1945' in Edeltraud Klueting ed., Antimodernismus und Reform (Darmstadt 1991), 191-215; Thiesse, Écrire la France, 261-286; Christian Faure, Le projet culturel de Vichy (Paris 1989); Stefano Cavazza, Piccole Patrie. Feste populari tra regione e nazione durante il fascismo (Bologna 1997); and João Leal, Ethnographias Portuguesas (1870-1970). Cultura popular e identidade nacional (Lisbon 2000).

${ }^{14}$ See for Germany Klaus Bergmann, Agrarromantik und Großstadfeindlichkeit (Meisenheim am Glan 1970); and Werner Hartung, Konservative Zivilisationskritik und regionale Identität am Beispiel der niedersächsischen Heimatbewegung 1895 bis 1919 (Hannover 1991).

${ }^{15}$ For Germany see, for example, Hannjost Lixfeld, Folklore and Fascism. The Reich Institute for German Volkskunde (Bloomington 1994); Willi Oberkrone, Volksgeschichte. Methodische Innovation und völkische Ideologisierung in der deutschen Geschichtswissenschaft, 1918-1945 (Göttingen 1993); Elizabeth Boa and Rachel Palfreyman, Heimat. A German Dream. Regional Loyalties and National Identity in German Culture, 1890-1990 (Oxford 2000); Andreas Knaut, Zurück zur Natur! Die Wurzeln der Ökologiebewegung (Greven 1993); William H. Rollins, A Greener Vision of Home. Cultural Politics and Environmental Reform in the German Heimatschutz Movement 1904-1918 (Ann Arbor 1997); Winfried Speitkamp, Die Verwaltung der Geschichte. Denkmalpflege und Staat in Deutschland 1871-1933 (Göttingen 1996); and Alon Confino, The Nation as a Local Metaphor. Württemberg, Imperial Germany and National Memory (Chapel Hill 1997).

${ }^{16}$ For Zuloaga, see Enrique Lafuente Ferrari, La vida y el arte de Ignacio Zuloaga (1949; Barcelona 1990); and Francisco Calvo Serraller, Paisajes de luz y muerte. La pintura española del 98 (Madrid 1998).

${ }^{17}$ See Javier Tusell, Arte, historia y política en España (1890-1939) (Madrid 1999); Paisaje y figura del 98 (Madrid 1997); José Luis Bernal Muñoz ed., La mirada del 98. Arte y literatura en la Edad de Plata (Madrid 1998); and Alberto Villar Movellan, 'Arte y región en los confines del 98', Gades, 23 (1999), 67-80.

${ }^{18}$ See for example Michael R. Orwicz, The representation of the Breton: Art Criticism, Politics and Ideology in Paris, 1885-1889 (Diss. UCLA 1989); Daniel Le Couedic and Jean-Yves Veillard eds., Ar Seiz Breur. La création bretonne 
entre tradition et modernité (Rennes 2000); and Joes Segal, Krieg als Erlösung. Die deutschen Kunstdebatten 19101918 (München 1997).

${ }^{19}$ James D. Herbert, Fauve Painting. The Making of Cultural Politics (New Haven and London 1992); and Magdalena Bushart, Der Geist der Gotik und die expressionistische Kunst (München 1990).

${ }^{20}$ Recently, some of these architects have received new attention. See Jean-Claude Vigato, L'architecture régionaliste. France 1890-1950 (Paris 1994); Daniel le Couédic, Les architectes et l'idée bretonne 1904-1950 (Rennes 1995); D. Calabi, 'Marcel Poète; pioneer of "l'urbanisme" and defender of "l'histoire des villes"', Planning Perspectives (1996), 413-436; Catherine Bruant, 'Histoire - Donald Alfred Agache (1875-1959). L'urbanisme: "une philosophie sociale"', Urbanisme 321 (2001), 77-83; Jean-Pierre Frey, 'Questions? Gaston Bardet, theoreticien de l'urbanisme "culturaliste", Urbanisme 319 (2001), 32-36; Vittorio Lampugnani and Romana Schneider eds., Moderne Architektur in Deutschland 1900 bis 1950. Reform und Tradition (Stuttgart 1992); Gerhard Fehl, Kleinstadt, Steildach, Volksgemeinschaft. Zum 'reaktionären Modernismus' im Bau- und Stadtbaukunst (Braunschweig and Wiesbaden 1995); Barbara Millar Lane, National Romanticism and Modern Architecture in Germany and the Scandinavian Countries (Cambridge 2000); N. Basurto, Leonardo Rucabado y la arquitectura montañesa (Madrid 1986); and A. Villar Movellán, La arquitectura del regionalismo en Sevilla (1900-1936) (Sevilla 1975).

${ }^{21}$ Martin Wörner, Vergnügen und Belehren. Volkskultur auf den Weltausstellungen 1850-1900 (Münster 1999); Bjarne Stoklund, 'How the Peasant House Became a National Symbol. A Chapter in the History of Museums and NationBuilding', Ethnologia Europaea, Vol. XXIX (1999), 5-18; M. Trillo de Leyva, La Exposición Iberoamericana de Sevilla (Sevilla 1980); and Shanny Peer, France on Display. Peasants, Provincials and Folklore in the 1937 Paris World's Fair (Albany 1998).

22 James D. Herbert, Paris 1937. Worlds on Exhibition (Ithaca 1998), 19.

${ }^{23}$ See also: Lane,National Romanticism and Romy Golan, Modernity and Nostalgia: Art and Politics in France Between the Wars (New Haven 1995).

${ }^{24}$ See for example Applegate, A Nation of Provincials, 12 and 60; Hermann Bausinger, 'Heimat in einer offenen Gesellschaft. Begriffsgeschichte als Problemgeschichte' in Will Cremer and Ansgar Klein ed., Heimat, Analysen, Themen, Perspektiven (Bielefeld 1990), 76-91; Thiesse, Écrire la France, 12-13; and Núñez, 'The Region as Essence', 491-508.

${ }^{25}$ Charlotte Tacke, 'National Symbols in France and Germany in the Nineteenth Century' in Heinz-Gerhard Haupt, Michael Müller and Stuart Woolf eds., Regional and National Identities in Europe in the XIXth and XXth Centuries (The Hague 1998), 412-413. The same applies to other dichotomies that were used to define the respective identities like Civilization-Kultur and Mediterranean Classicism versus Northern Romanticism. 